\title{
EVALUATION OF MECHANICAL CHARACTERISTICS OF THE INTERLOCKING CONCRETE PAVES PRODUCED FLY ASH
}

\author{
Can DEMIREL ${ }^{* 1}$, Bahattin ÖZTOPRAK ${ }^{2}$, Osman ŞİMŞEK ${ }^{3}$ \\ ${ }^{*}$ Department of Construction, Kirklareli University, Kırklareli, Turkey \\ ${ }^{2}$ Department of Construction, Bolu Izzet BaysalUniversity, Bolu, Turkey \\ ${ }^{3}$ Department of Civil Engineering, Gazi University, Ankara, Turkey
}

\begin{abstract}
Fly ashes are used as pozzolanic admixtures or filler materials in concrete production. Increasing the use of fly ash is important both in terms of economy and environmental pollution. The interlocking concrete paves are commonly used in urban streets and pavements, in factory surroundings and etc. Interlocking concrete paves shall be above the minimum strength specified in TS 2824 EN 1338 standard.

In this study, fly ash has been used as a substitute to cement in 0, 10, 20, 30, 40 and 50\% ratios. The splitting tensile strength and water absorption characteristics of the pave have been determined. The usage of the FA in the production concrete pave is a higher quality production, more economical and a more environmentally friendly approach.
\end{abstract}

Keywords: Concrete Paves, Fly Ash, Splitting tensile strength test.

\section{UÇUCUKÜL İKAMESİ İLE ÜRETİLEN BETON KILITLII PARKE TAŞLARININ MEKANIK ÖZELLIKLERININ DEĞERLENDİRILMESI}

\section{Özet}

Uçucuküller beton üretiminde puzolanik katkı veya dolgu (filler) malzemesi olarak kullanılmaktadır. Uçucukül kullanım alanının arttırılması hem ekonomi hem de çevre kirliliği açısından önemlidir. Beton kilitli parke taşları, yaygın olarak şehir içi yol ve kaldırımlarda fabrika çevreleri ve benzeri yerlerde kullanılmaktadır. Beton kilitli parke taşlarının özellikle TS 2824 EN 1338'de standartta belirtilen minimum dayanımının üstünde olması gerekmektedir.

Corresponding author: candemirel@klu.edu.tr, https://orcid.org/0000-0003-0417-8327 
Çalışmada uçucu kül \% 0, 10, 20, 30, 40 ve 50 oranlarında çimento yerine ikame edilerek kullanılmıştır. Üretilen parke taşlarının yarmada çekme, su emme ve aşınma özellikleri saptanmıştır. UK’nin parke taşı üretiminde kullanılması, daha iyi parke taşı üretimi, ekonomiklik ve çevre açısından iyi bir yaklaşım olacaktır.

Anahtar Kelimeler: Beton Parke Taşı, Uçucukül, Yarmada Çekme Dayanımı Testi.

\section{INTRODUCTION}

Concrete lock parquet stones are constructional components produced via parquet machine by mixing concrete, aggregate, water and other additives when required at certain amounts [1].

Parquet road construction is a type of superstructure used since the Romans. Stone block pavement application was the only solution with the application of pavement coating, durability, clean and as a surface appropriate for wheel-rolling was the only solution before the use of hydrocarbon bonding agents (asphalt, tar etc.). It still possible to encounter this type of paved roads, which are called as "Albanian Pavement" in our country [2].

As a result of the increase in demand of aesthetics over time, parquet stones with smooth sized natural stone materials that require a certain workmanship have been used. However, the long production period of the production of the parquet stones provided from natural sources and the increasing demand have caused the costs to increase. Due to the fact that it is formed of rigid parts which are clamped together, prefabricated concrete pavements approaching to the rigid coating category, on the other hand, thanks to the interlace to the lower layer present elastic behaviour in conveying the load to this layer and can show the quality of flexible coating. Therefore, it is possible to place locked concrete parquet coatings among rigid and flexible coatings due to the approach sometimes to asphalt and sometimes to the concrete coating [1].

Joints must be checked in concrete roads and joints fillings should be changed every 4-5 years. As for asphalt roads, it is necessary to repair the defects caused by cracking, cavitation or decompositions in shorter periods. However, it has been determined that the locked concrete paving coating does not require maintenance for 25 years after construction [3].

When the physical, chemical and mineralogical properties of the UK are examined, it is considered possible that these can be used easily in the construction sector and thus while the economy is 
ensured in the production of materials and energy, it is also possible to protect the ecological balance by preventing the pollution of the environment [4].

Low calciferous UKs, observed according to the results of different research; reduce the water need in a constant $\mathrm{N} / \mathrm{E}$ ratio; that is to say, increase processability. UKs with high levels of lime reduce processability $[5,6,7,8]$.

\section{MATERIAL AND METHODS}

In the production of the concrete lock stone, the P 42.5 cement provided from Limak Çimento, Ankara, and the 0-4 class of broken stone from Ankara Limak Beton administration were used.

In this study Çayırhan fly ash was used. It is also included in limy ash class since its SiO2, AL2O3, $\mathrm{Fe} 2 \mathrm{O} 3$ levels are over \% 70, and besides including class F (low calciferous), its analytical $\mathrm{CaO}$ amount is over \% 10 [9].

Ankara network water was used as mixing water.

Table 1. Chemical characteristics of CEM I 42.5 R and UK.

\begin{tabular}{ccr}
\hline \hline Chemical composition & Cement $(\%)$ & Fly ash (\%) \\
\hline $\mathrm{SiO}_{2}$ & 14.73 & 50.88 \\
$\mathrm{Al}_{2} \mathrm{O}_{3}$ & 4.80 & 13.34 \\
$\mathrm{Fe}_{2} \mathrm{O}_{3}$ & 3.61 & 10.09 \\
$\mathrm{CaO}$ & 64.29 & 13.09 \\
$\mathrm{MgO}$ & 0.85 & 5.50 \\
$\mathrm{SO}$ & 2.40 & 3.32 \\
$\mathrm{Na}_{2} \mathrm{O}$ & 0.30 & 2.59 \\
$\mathrm{~K}_{2} \mathrm{O}$ & 0.79 & 2.72 \\
\hline
\end{tabular}

In the visual inspection of the locked paving stone there should be no cracks, gaps on the surface, cavitations and roughness. Prepared mortar is manufactured by applying 10sec vibration in the locked parquet stone machine. Samples from the mould were irrigated via sprinkler method 2 times a day for 1 week (morning and evening) and once a day on other days. 

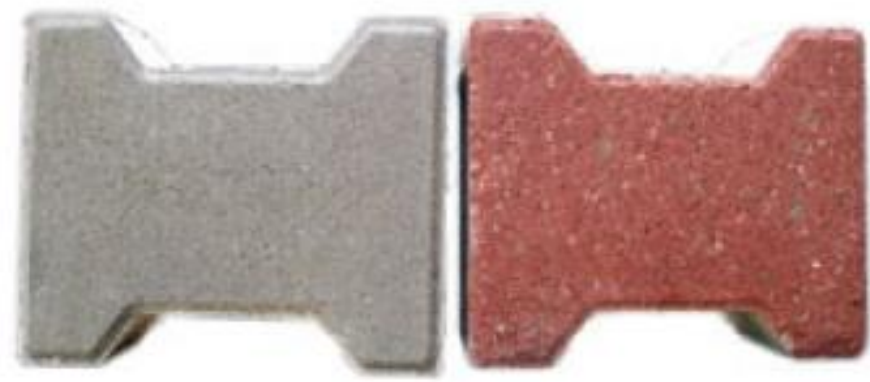

Figure 1. Concrete locked paving stone.

Table 2. Material amount put into the concrete mixture (for $1 \mathrm{~m} 3$ )

\begin{tabular}{|l|llllll|}
\hline Materials & Ref. & $\% 10 \mathrm{UK}$ & $\% 20 \mathrm{UK}$ & $\% 30 \mathrm{UK}$ & $\% 40 \mathrm{UK}$ & $\% 50 \mathrm{UK}$ \\
\hline $\begin{array}{l}\text { Aggregate 0-4 mm. } \\
\text { (kg.) }\end{array}$ & 1573 & 1573 & 1573 & 1573 & 1573 & 1573 \\
Cement (kg.) & 340 & 306 & 272 & 238 & 204 & 170 \\
UK (kg.) & 0 & 34 & 68 & 102 & 136 & 170 \\
Water (Lt.) & 180 & 180 & 180 & 180 & 180 & 180 \\
\hline
\end{tabular}
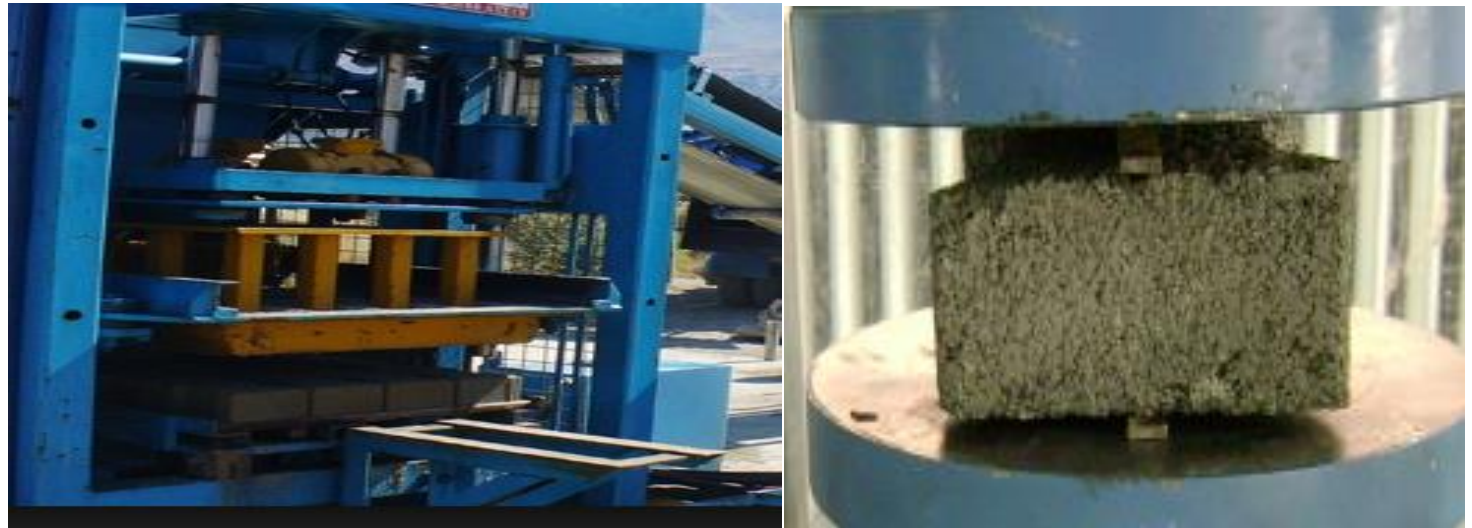

Figure 2. Concrete locked parquet stone production

Figure 3. Splitting tensile test

Splitting tensile test was conducted according to TS 2824 EN 1338. Concrete lock was steeped in water at $(20 \pm 5){ }^{\circ} \mathrm{C}$ for $(24 \pm 3)$ hours before testing. When taken out of water, the sample was dried a cloth and tested [10]. 


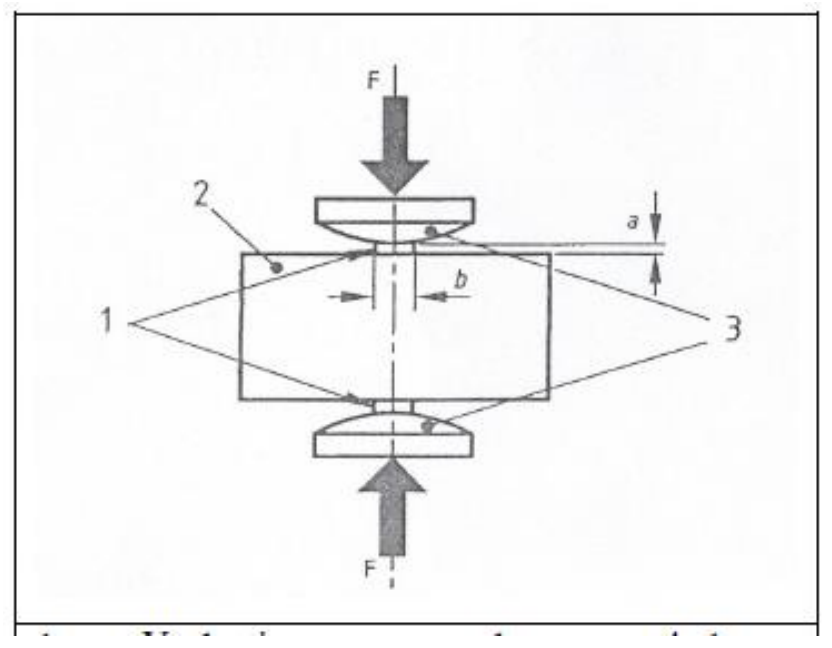

Figure 4. Splitting tensile strength test principle [9].

The fracture plane area of the concrete keypads tested is calculated using the equation given below:

$$
S=l \times t^{\prime}
$$

Here;

S: Refraction area, $\mathrm{mm}^{2}$

1: Length of the fracture cross-section as the average of the two measurements made at the top and bottom of the concrete lock stone

t: the thickness of the concrete lock stone on fracture plane area as the average of three measurements, one in the middle and the other two from the sides, (mm).

According to TS 2824 EN 1338, the mean values of the splitting tensile strengths are demanded not to be less than 3.6 MPa or each result should not be less than 2.8 $\mathrm{MPa}$. The splitting tensile strength $(\mathrm{T})$ of the specimen which undergo a test is calculated by the equation below:

$$
T=0637 \times k \times P / S
$$

Here;

$\mathrm{T}$ : Strength, MPa

P: Breaking load, N 
$\mathrm{k}$ : It is the adjustment coefficient for the thickness of the parquet stone which is calculated by the following equation or taken from Table 3.

Table 3. "k" adjustment coefficient.

\begin{tabular}{|l|l|l|l|l|l|l|l|l|l|l|l|}
\hline$(\mathrm{mm})$ & 40 & 50 & 60 & 70 & 80 & 90 & 100 & 110 & 120 & 130 & 140 \\
\hline $\mathrm{k}$ & 0,71 & 0,79 & 0,84 & 0,94 & 1,00 & 1,06 & 1,11 & 1,15 & 1,19 & 1,23 & 1,25 \\
\hline
\end{tabular}

Before water absorption is determined, dust, loose parts, etc. on Test samples are cleaned with a brush and the samples are ensured to be at $(20 \pm 5)^{\circ} \mathrm{C}$. Water absorption test was conducted according to TS 2824 EN1338 [10]. After the samples were stored in water at $20 \pm 2 \mathrm{C}$ for 72 hours, their saturated surface dry-weights were recorded (M1). In order to determine the dry weight values (M2) of the samples, the dry weights of the samples, which were kept at $10572 \mathrm{C}$ for 72 hours in ventilated ovens, were recorded. Water absorption of each sample (ta) is calculated in percent by mass using the equation given below [10].

$$
t a=(M 1-M 2) / M 2 \%
$$

Here;

M1 first mass of the test sample, $\mathrm{g}$.

M2 last mass of test sample, $\mathrm{g}$.

According to TS $2824 \mathrm{EN} 1338$ (9), the water absorption rate should not be more than 5\% on average and should not be more than $7 \%$ at a single sample.

Abrasion strength, according to ASTM C 944 (21); has been executed by abrasing the upper side of the parquet stone with abrasive wheel under standard conditions. 


\section{RESULTS AND DISCUSSION}

The water absorption rate values of the prepared samples are given in Table 4.

Table 4. Water absorption rate test results

\begin{tabular}{|c|c|c|}
\hline Samples & $\mathrm{N}$ & Water absorption rate \\
\hline Ref & 9 & 5.91 \\
$\% 10$ & 9 & 6.03 \\
$\% 20$ & 9 & 6.21 \\
$\% 40$ & 9 & 6.62 \\
$\% 50$ & 9 & 7.48 \\
\hline
\end{tabular}

Generally speaking, the rate of water absorption increases as the UK substitution rate increases. $50 \%$ UK substituted mixture exhibits the highest water absorption rate. It is $31 \%$ higher than the arbitration sample. $10 \%$ UK substituted mixture is $2 \%$ more than the reference mixture.

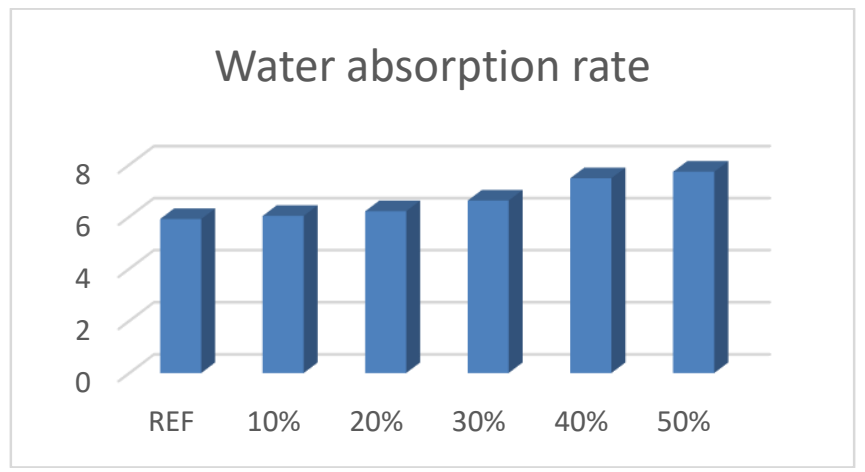

Figure 5. Water absorption values.

Water absorption values; values above the recommended limit value in TS 2824

\section{EN1338 / AC in all samples.}

The results of the abrasion test results of the prepared samples are given in Table 5. 
Table 5. Abrasion test results

\begin{tabular}{|cc|}
\hline Samples & Abrasion rate \\
\hline Ref & 0.145 \\
$\% 10$ & 0.193 \\
$\% 20$ & 0.256 \\
$\% 30$ & 0.324 \\
$\% 40$ & 0.429 \\
$\% 50$ & 0.567 \\
\hline
\end{tabular}

As the substitution rate increases, the abrasion resistance decreases proportionally. $\mathrm{K} 50 \% \mathrm{UK}$ substituted samples have exhibited the lowest abrasion resistance. Abrasion resistance decreases as UK substitution rate increases.

The splitting tensile strengths in the prepared samples are given in Table 6. When Table 6 is examined, increase in the strength of the concrete lock stone is observed as the age increases.

In the 7-day test results, $10 \%$ substitution mixture exhibited higher resistance than the arbitration sample. It was seen that there was a \%5.19 increase compared to the arbitration sample. The lowest value is seen in $40 \%$ and $50 \%$ fly ash substituted mixtures.

When the 28-day test results were examined, $10 \%$ substitution mixture showed higher strength than the arbitration sample. An increase of \%5.34 in proportion to the arbitration sample has been observed.

When 90-day test results were examined, \%10 substitution mixture and \%20 substitution mixture increased $\% 14$ and $\% 1.3$ relatively compared to the arbitration sample. The lowest values are seen in mixtures with $40 \%$ and 50\% fly ash substitutes. Relatively $\% 20$ and $\% 23$ lower strength has been observed compared to the arbitration sample. $30 \%$ fly ash substitution mixture has exhibited $3 \%$ less strength than the arbitration sample.

The increase in the UK substitution rate caused an increase in the water demand of fresh concrete. Since the $\mathrm{S}$ / Ç ratio is kept stable, the high UK samples are not well tightened. Therefore, strength in $40 \%$ and $50 \%$ fly ash substituted mixtures can be considered to be low. 
Table 6. Splitting tensile test results

\begin{tabular}{|c|c|c|c|c|}
\hline Samples & N & $\begin{array}{c}\text { 7 Days } \\
\text { (Average Mpa) }\end{array}$ & $\begin{array}{c}\text { 28 Days } \\
\text { (Average Mpa) }\end{array}$ & $\begin{array}{c}90 \text { Days } \\
\text { (Average Mpa) }\end{array}$ \\
\cline { 1 - 1 } Ref & 9 & 2.19 & 2.62 & 3.27 \\
\cline { 1 - 1 }$\% 10$ & 9 & 2.31 & 2.76 & 3.72 \\
\cline { 1 - 1 }$\% 20$ & 9 & 2.11 & 2.48 & 3.31 \\
\cline { 1 - 1 }$\% 30$ & 9 & 2.05 & 2.32 & 3.16 \\
\cline { 1 - 1 }$\% 40$ & 9 & 1.98 & 2.19 & 2.60 \\
\cline { 1 - 1 }$\% 50$ & 9 & 1.76 & 2.08 & 2.52 \\
\hline
\end{tabular}

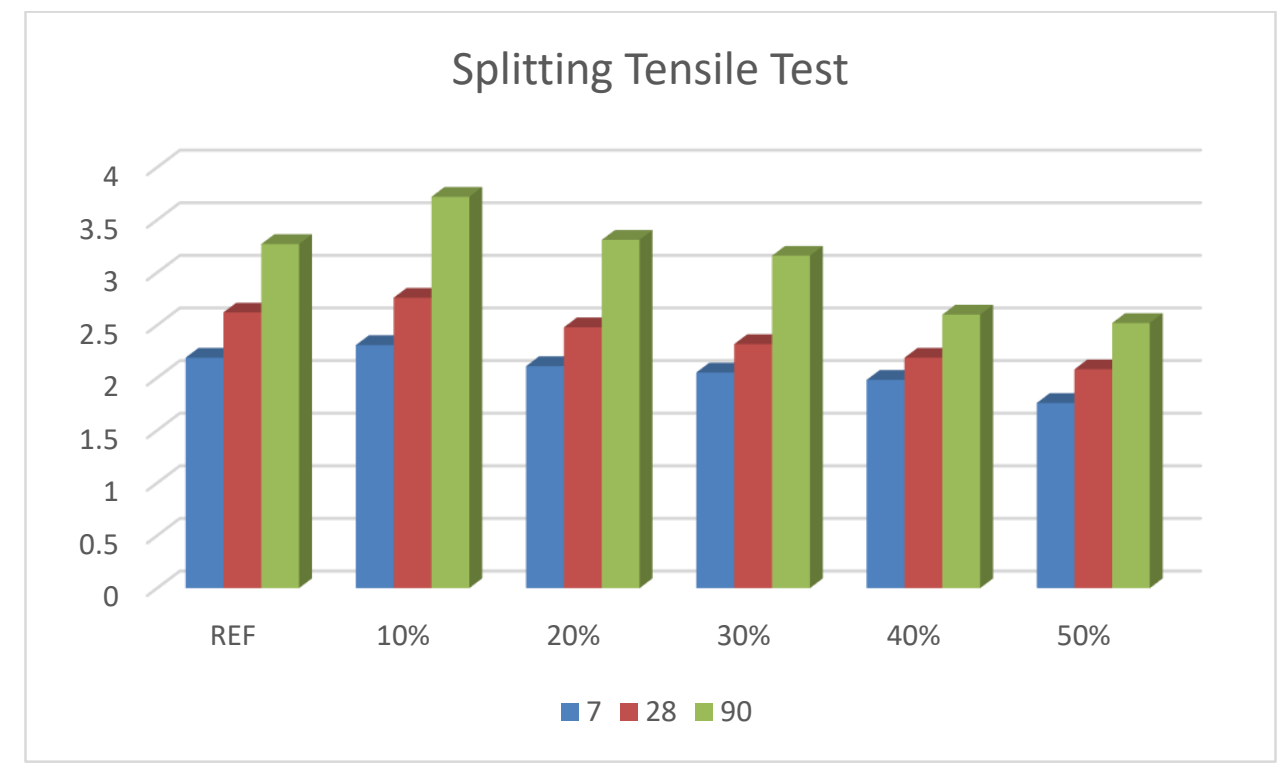

Figure 6. Splitting tensile test graphics of the sample.

\section{CONCLUSION}

A key factor in the production of locked parquet stones is the cost. The most important factor increasing the cost is the amount of cement. Therefore, the amount of aggregate can be increased to reduce the amount of cement or the amount of cement can be reduced by using waste materials such as fly ash and slag in KBPB composition. Thus, the cost will reduce with use of these wastes. 
In addition, these waste materials will be reintroduced to the economy and environmental pollution will be prevented.

It is thought that in samples with high UK substitution rate, the compression time applied during production can bear better results if kept longer.

The increase in the UK substitution rate caused an increase in the water demand of fresh concrete. Since the $\mathrm{S} / \mathrm{C}$ ratio is kept stable, the samples with high UK rates are not well tightened. Therefore, strength in $40 \%$ and $50 \%$ fly ash substituted mixtures can be considered to be low.

UK use reduced the abrasion resistance.

\section{REFERENCES}

[1] Semiz, M, Beton Kilit Taslarının Fiziksel Özellikleri ve Alternatif Üretimin Arastırılması, Yüksek Lisans tezi, Gazi Üniversitesi Fen Bilimleri Enstitüsü, Ankara, 1-20, 2006.

[2] Tunç, A,, Yol Malzemeleri ve Uygulamaları, Atlas yayın dağıtım, İstanbul, 466-467, 2001.

[3] Öztaş, G., Ağar, E, Kilitli Beton Parke Kaplamalar, şantiye insaat Makine ve Mimarlık Dergisi, (18): 98-102, 2005.

[4] Aruntaş, H.Y., Uçucu Küllerin inşaat Sektöründe Kullanım Potansiyeli, Gazi Üni. Müh. Mim. Fakültesi Dergisi, 21 (1): 193-203, 2006.

[5] Simsek O., Aruntaş H.Y., Fırat S., " Çayırhan ve Soma-B Termik santrali uçucu küllerinin beton basınç dayanımına etkisi", Türkiye inşaat Mühendisliği16.Teknik Kongre ve Sergisi, 199205, 2001.

[6] Erdoğan T.Y, Beton, ODTÜ, Ankara,183-189, 2003.

[7] Türker, P, Erdoğan, B, Kantaş, F, Yeğinobal1, A., Türkiye'deki Uçucu Küllerin Sınıflandırılması ve Özellikleri, Türkiye Çimento Müstahsilleri Birligi Ankara 20-34, 2003

[8] D. Gökhan, O. Şimşek, Türk Bilim Araştırma Vakfı Bilim Dergisi 1(1) 1-6. 2008

[9] ASTM C 618, (). Standart specificationforCoalFlyAshandRaworCalcined Natural PozzalanforUse as a Mineral Admixture in Concrate, AnnualBook ofASTM Standarts, 4-16, 1998. [10] TS 2824 EN1338/AC: Zemin döşemesi için beton kaplama blokları - Gerekli Şartlar ve DeneyMetotları, TSE, Ankara-Türkiye. 2009. 
[11] ASTM C 944, "Standart Test Method For Abrasion Resistance of Concrateor Mortar Surfaces by The Rotating - Cutter Method", American Sociesty For Testing and Materials, USA, 1- 4. 